\title{
Neotectonic Impact on the Archaeological Site of Castellum Tidditanorum (Tiddis) -NE of Algeria
}

\author{
Foued Bouaicha $^{1 *}$, Kamel Boufaa ${ }^{1}$ and Nabil Manchar ${ }^{2}$ \\ ${ }^{1}$ Constantine 1 University, Algeria \\ ${ }^{2}$ University of Larbi Ben M'Hidi, Algeria \\ *Corresponding author: Foued Bouaicha, University of Frères Mentouri, Constantine 1 University, Algeria \\ Submission: 眥September 22, 2017; Published: 眥 October 27, 2017
}

\section{Opinion}

Seismic events and its spatial distribution is an effective tool for the assessment of archeological hazard. Geologists in theunderstanding of the geodynamic properties of the region help engineers to develop a new constructional method to reduce the intensity of the seismic risk. Though the effect of seismic activities on archaeological remains doesn't simply achieve with one destroy event; it is acontinuing process that may go on to destroy the archaeological remains [1].

The north Africa area is famous for its archaeological abundance and its recurrent earthquakes. Recently geologists, seismologists, engineers, historians, and archaeologists have begun to interest and collaborate methodically in research and heritage risk management.

The north-eastern region of Algeria contains a variety of archaeological and prehistoric remains that arebadly exploited and abandoned. The wilaya of Constantine has a rich cultural heritage, the Roman ruins of Castellum Tidditanorum (Tiddis) which is one of the best-known archaeological sites in the region.

The deformation, distortion, and damage recorded in almost all the buildings in the town of Tiddis are likely to be of seismic origin. Indeed, given the current seismicity data for northern Algeria, which is almost 30 years old, it is easy to make believe a very large number of seismic shocks expanded over a period more than 2000 years. The impact of this repeated seismicity is likely to be the cause of the repeated destruction and consequently the different phases of reconstruction resulting from it. Rock fall, rock slides and debris slides origin would no doubt be explained by seismic activity.

The proposed work can be expanded and completed in the light of the results of other similar work undertaken in other regions of the world. Indeed, within the framework of the IGCP (International Geoscience Program) program and in particular IGCP 567. Research results in highly seismic countries with a very important archaeological heritage have been created. An example is the work of Despina Minos-Minopoulos [2], who was able to establish an exhaustive classification of the effects of earthquakes on an Earthquake Archaeological Effect archaeological site (EAE), but also the work of the APS group, identification, and study of pathologies of seismic origin in ancient buildings.

\section{References}

1. http://www.unesco.org/new/fr/natural-sciences/environment/earthsciences/international-geoscience-programme/

2. Minos-Minopoulos D, Pavlopoulos K, Lekkas E, Dominey-Howes D (2015) Earthquake Archaeological Effects (EAEs) from the archaeological site of Ancient Corinth, Greece and their correlation to seismic events. $6^{\text {th }}$ International INQUA Meeting on Paleoseismology, Active Tectonics and Archaeoseismology, Pescina, Fucino Basin, Italy, pp. 19-24. 